\title{
IS NEUTRALITY AN APPROPRIATE INSTRUMENT FOR DOMESTIC SECURITY? A EUROPEAN PERSPECTIVE
}

\author{
Christian LANZ
}

\begin{abstract}
Can the Law of Neutrality, as still practised by various countries in Europe today, still prevent or protect from a war or a conflict? How compatible, if at all, is neutrality with affiliation to supranational organisations, e.g. the UN or the European Union and other international security organisations and agreements, and finally, can it contribute to domestic security? Even if the TV station Al-Jazeera broadcasted excerpts of a videotape of Osama Bin Laden addressing the American people by quoting: (...) "Let him (President Bush) tell us why we did not strike Sweden, for example." (...) we have to look at features, relevance and history of neutrality and at today's actual security situation. The analysis of the European security situation reveals a manifold range of threats and risks, which has developed particularly through the creeping dissolution of the monopoly of national power, e.g. unresolved conflicts in the South-Eastern flank of Europe, the phenomenon of organised crime trying to integrate itself into the economic operation, the constantly growing willingness of terrorists to commit suicide attacks, the spread of WMD, etc. It can be noted that the danger of conventional military threats has clearly diminished. It is, however, evident that the new conflict potential and its forms are characterised by ethical, religious and also economically motivated actors (usually non-governmental) and that they considerably affect the safety environment of Europe. So a question must be asked, to what extent neutrality is still of use in such an environment.
\end{abstract}

Keywords: Law of Neutrality, Hague Conventions, Charter of the United Nations, Prohibition of War, Integration of the European States, Creeping Dissolution of the Monopoly of National Power, Blurring Borders between External and Internal Security, Networking.

The term "neutrality" is defined by the international community as non-participation in armed conflicts between other states. A distinction must be made, however, between the Law of Neutrality and the policy of neutrality. 
The Law of Neutrality is that area of International Law containing those provisions which neutral states have to observe in times of international armed conflict and to which the parties of the conflict must adhere in the same context. For the most part, these concern the right of the neutral states to be left undisturbed during such conflicts and their obligations of impartiality and non-participation. In practice, such obligations do not interfere greatly with the freedom of action of neutral states. The sources of the international Law of Neutrality are customary International Law on one hand and the 1907 neutrality agreements of The Hague on the other.

The policy of neutrality concerns all measures that a neutral state decides to adopt of its own free will, above and beyond its legal obligations, so as to ensure the credibility and effectiveness of its neutrality. Neutrality policy is flexible enough to adapt to each case, taking into account the foreign and security policy situation of the day. ${ }^{1}$

Can the Law of Neutrality - as still practised by various countries in Europe today, among others Switzerland, Finland, Austria and Sweden - still prevent or protect from a war or a conflict? How compatible, if at all, is neutrality with affiliation to supranational organisations, e.g. the UN or the European Union and other international security organisations and agreements?

The increasing interdependence of trade, economics, and, above all, information (globalisation) present a further challenge for neutrality as the existence of a society or even a state can increasingly be threatened by more than foreign armed forces alone. Europe, in particular, currently faces no direct military threat any more. Of course the question arises here too, what or whether neutrality can contribute to domestic security. Therefore, the neutrality question will have to be judged with particular regard to the risks and dangers facing Europe. These are the central questions to be discussed in this article.

\section{Features and Relevance of Neutrality}

The right of neutrality contains those regulations of International Law that must be considered by states in the event of international armed conflict. The general regulations of the Law of Neutrality were contractually codified (land and naval warfare) in 1907 at the Hague Peace Conference. Until today, there have been no further written additions to this Law of Neutrality; it has only been augmented and extended by unwritten International Law. The Law of Neutrality is only applicable to inter-governmental conflicts, not however to internal conflicts or civil wars. The neutrality right is also not applicable if the United Nations takes action to preserve international peace and security, for example when a state has violated the Charter of the United Nations. So the right of neutrality can principally not be applied to coercive measures of the UN due to the fact that according to The Hague Conventions ${ }^{2}$ a conflict between the 
UN and a lawbreaker does not constitute a military conflict between states. Consequently, one could also say that with the Charter of the United Nations neutrality no longer exists since the Charter foresees no neutrality at all, as war is principally prohibited and peace is regarded as the normal condition.

A short review of history must be made to better comprehend the nature of neutrality. The international policies of the years 1648 to 1900 can be also designated as the "Westphalia order," since certain aspects of that policy were upheld more or less continuously. Three of these components are thereby of special importance:

1. The neighbourhood of sovereign and independent national states;

2. The acceptance of war as instrument for regulating conflicts, thus no general prohibition of war;

3. Tolerance of non-involvement in wars.

These components are no longer compatible with today's order since after the two totalitarian World Wars a complete reorientation of the international order developed. From there on, wars were no longer accepted as legal means for resolving a conflict, with the exception of the coercive measures already mentioned in the context of the United Nations and the more or less clearly defined right of self-defence. So, we can conclude that neutrality in the classical sense had already lost its legal basis after $1945 .^{3}$ For the first time, the conditions between the European states were no longer determined by war, but through cooperation and collaboration.

Apart from the obligations of neutral states, it remains to be mentioned that the neutral states still have rights. ${ }^{4}$ If it is embroiled in a war, the neutral state is allowed to join alliances or make use of foreign military support. Neutrality obligations become obsolete, if neutrality fails to fulfil its function. Here, however, the question arises, for how long war preparations (today: threats of terror?) of a foreign power, for example, must be tolerated, even when these are also directed against a neutral state without affecting its territorial sovereignty. Which preparations or cooperation arrangements can be made by the neutral state in times of peace without compromising state's neutral status?

Since the end of the Cold War, there have been interventions not only in international conflicts, but also in cases of humanitarian disasters or severe violations of human rights, such as these in former Yugoslavia, Somalia, Kosovo, etc. This results in the fact that even states no longer enjoy unlimited sovereignty and that they can very well forfeit their sovereignty if they are universally seen to violate International Law. This universal view of right and injustice, however, is of greatest importance for the success of such an intervention. The partly independently conducted pre-emptive strikes ${ }^{5}$ of the United States of America (USA), particularly in the case of the Iraq 
intervention in the aftermath of 9-11, demonstrated an even greater restriction in the sovereignty of a state. A universal consensus that Iraq had committed a breach of law did not exist as many states like France, Germany, China and Russia among others did not support the view of the United States. States involved in the intervention and in the subsequent pacification of Iraq, such as Spain and Italy, have already painfully had to find out what it means to have participated in an action that was not legitimised by International Law or was only legitimised later (abduction of citizens and assassinations some of which were even carried out in the home country). States not participating in this war, i.e. those European countries that remained neutral, so far have been spared attacks and encroachments (see also next section on this). At the present time, we may thus say that a certain degree of restraint or in other words taking a clearly neutral stance during a military dispute can certainly produce some security. ${ }^{6}$

However, the question must be posed, to what degree a state can remain neutral in the face of today's security policy integration.

Tolerance towards neutral states has, however, clearly diminished with the creeping dissolution of proper national states in Europe. Besides the UN and NATO, the European Union has also constantly developed further with regard to its Common Security Policy. Hardly any other region of the world knows such a high degree of integration and organisation between states. This is not only the case in the field of security but also in the economic sector with the European Union, European Fair Trade Association (EFTA), Organisation for Economic Cooperation and Development (OECD), etc. ${ }^{7}$ A central goal of the European Security and Defence Policy (ESDP) is to strengthen the Union's ability to act as an entity at the international level by establishing civilian and military capacities for conflict prevention and crisis management. The ESDP forms a part of the Common Foreign and Security Policy of the European Union and functions according to the principle of inter-governmental cooperation. With the 2004 Headline Goals passed by the European Council in July 2010, the creation of such crisis management capacities enters a new phase. Already by 2007, an intervention capability is to be established with 13 planned rapidly deployable units. ${ }^{8}$ The operational readiness of the ESDP has already been demonstrated with the conduct of several civilian and military operations. The first began on 1 January 2003, when the European Union Police Mission of 500 officers took over in BosniaHerzegovina from the UN's International Police Task Force. The mission, which will remain for a period of three years, is training local police officers and establishing sustainable policing arrangements in line with European standards and practice. The second operation followed later in 2003, when a small NATO force in Macedonia was replaced first by an EU military force, and subsequently by a 200 -strong EU police mission, which is still in place. The largest of the three started in December 2004, when an EU military force (EUFOR) took over from the previous NATO-led Security 
Force (SFOR) in Bosnia-Herzegovina. SFOR has been in place since the end of hostilities in 1995. EUFOR has a total of 8,000 troops. ${ }^{9}$

These developments show the increasing integration of the European states and their assumption of responsibility in all areas of crisis and conflict management. The holistic approach of transferring sovereignty and independence to a supranational organisation that is better able to act seems to have found acceptance. Respective noninvolvement (neutrality) indirectly weakens these efforts and will probably meet with little understanding.

\section{Security Policy Challenges}

When examining the practicality of security policy, the definition of political goals must be kept in mind and those threats considered that challenge them. The aims and goals of the European states are, both nationally and in the context of the supranational community, fairly congruent due to quite balanced cultural, political and social homogeneity. Their integration is also becoming more and more intricate through industrialisation, urbanisation and growing international trade. ${ }^{10}$ As example the author refers to the goals of the Union enumerated in the preamble of the European Constitution:

The Union's aim is to promote peace, its values and the well-being of its peoples.

The Union shall offer its citizens an area of freedom, security and justice without internal frontiers, and an internal market where competition is free and undistorted.

The Union shall work for the sustainable development of Europe based on balanced economic growth and price stability, a highly competitive social market economy, aiming at full employment and social progress, and a high level of protection and improvement of the quality of the environment. It shall promote scientific and technological advance.

$(\ldots)^{11}$

The analysis of the European security situation reveals a manifold range of threats and risks, which has developed particularly through the creeping dissolution of the monopoly of national power and simultaneous privatisation:

- Yet unresolved conflicts, the instability and the failure to establish a new national order in the south-eastern flank of Europe, in particular in Kosovo. Long-term solutions of the economic, social and socio-political problems in the former Yugoslav area are not apparent yet. The zones, in which military and political instability is latently present, already are or will probably increasingly become opportune retreat areas for clusters of organised crime, war criminals as well as radical Islamic fundamentalists. 
- The phenomenon of organised crime, which develops best against a background of reduced national power, economic deterioration (unemployment), poor social climate (isolation of refugees and displaced persons) and also a lack of perspective among young people. ${ }^{12}$ Here, organised crime tries to integrate itself into the economic operation of the states through money laundering, corruption and the purchase of company stocks, entire enterprises and real estate. But even the states themselves and their powers are affected as police and jurisdiction may also constitute infiltration targets. According to recent findings, we can also assume that terrorist networks collaborate closely with organised crime syndicates. The past distinction between ideologically motivated terrorists and organisations of organised crime driven by financial greed seems to be fading more and more. The merging of financial greed and terrorist ideology could breed a new dimension of danger to democratic states and systems of collective security and collective defence. ${ }^{13}$

- $\quad$ The spread of weapons of mass destruction is very likely to continue despite all international efforts. Recent examples are North Korea's declaration to possess nuclear weapons, as well as the unveiling of the proliferation network of the Pakistani nuclear scientist Abdul Qadeer Khan. According to official data, Khan, for example, transmitted nuclear modules to Iran. ${ }^{14}$ Apart from various nuclear programmes, chemical and biological weapons are also still being developed. The spectre of having no national control over these weapons will therefore probably continue to haunt us.

- The threat of terrorism, as primarily practised by Islamic fundamentalists, has sharply increased over the last years. The USA and/or their citizens all over the world, but also other states that are connected with the USA are most threatened. Various factors are responsible that the terrorist threat has reached to a hitherto unknown dimension: the constantly growing willingness of terrorists to commit suicide attacks, the readiness to cause even a great number of casualties (Madrid, Beslan, Iraq, etc.), the absolute refusal to distinguish between guilty and innocent people and the innovative use of civilian technologies (e.g. car bombs).

- Apart from political, economic and social changes, technological developments may increasingly add to the range of threats. Today, the relevant technological results of research and development come mainly from the private sector and can, therefore, also be all the more easily obtained by non-governmental players. Developments in nano-technology, genetics and biotechnology could cause great changes with implications also for future warfare and conflict management. 
- Illegal migration: continuous instability causes a constantly growing flow of emigrants to Europe. Most of them are economic migrants who have no prospect of obtaining a refugee status and thus generate social risks, imbalance on the job market, wage pressure and promote xenophobia among the inhabitants of the host countries.

In summary, it can be noted that the danger of conventional military threats has clearly diminished. It is, however, evident from the enumeration above that the new conflict potential and its forms are characterised by ethical, religious and also economically motivated actors (usually non-governmental) and that they considerably affect the safety environment of Europe. So the question must be asked, to what extent neutrality is still of use in such an environment.

\section{Conclusion and Evaluation}

The trends make clear that terms such as internal and foreign security used so far are noticeably merging. The borders are blurring between domestic security (internal security) and foreign threats on the one hand and between respective defence, precautionary measures and competencies on the other. Europe has become a technologically highly advanced, specialised, globally networked and service-oriented society with a highly specialised industry. Already for quite a long time, the borders of the national state no longer correspond to network boundaries or to security areas. Even large distances offer no protection any more. The effects of violent conflicts are rapidly noticeable world-wide. Because of continuous domestic conflicts, this can express itself, for example, in streams of refugees, who rapidly set off crises in neighbouring countries.

If we intend to fight these new risks and dangers as well as their often forgotten causes, it becomes evident that here too, many new areas of cooperation will be necessary. The following areas will primarily have to be dealt with to enhance security:

- National and international interoperability (standardisation);

- Information exchange and common use of information ("from information sharing to information awareness") of the security services (intelligence) and the emergency organisations (first responders);

- Increased and coordinated approach against organised crime syndicates and possibly also operations against small crime by reinforcing police forces and paramilitary forces, e.g. Gendarmerie;

- Protection of critical infrastructures (integration of civilian authorities and their responsibilities) and the population; 
- Crisis management, particularly with regard to conflict prevention (cultural dialogue, economic cooperation and integration, privatisation, fight against corruption, etc.);

- Improvement of information (IT) security;

- Increase of the quality of sensor technology, monitoring and identification, particularly with regard to biometrics;

- $\quad$ Last but not least: calming down and reassuring the population. We should inform the public that terrorists are best defeated when people aren't afraid of them. ${ }^{15}$

During the latest international stabilisation operations it has also become evident, that apart from their classical combat missions, the armed forces will also have to increasingly carry out protective and preventive tasks. The result will thus be an increased mixture of military and police tasks. But this is a grey area, as basic legal conditions are still missing or inadequate. The sharp separation between military, political, economic and social resources for resolving conflicts has become increasingly difficult, since all means are inter-dependent in various ways during the different phases of conflict management. Only a continuous, trans-national, inter and intradepartmental dialogue (up to networking) and the resulting joint analysis will guarantee purposeful action in the future, economic use of resources and means as well as effective security provisions. ${ }^{16}$

The concept of integrated (networked) conduct of operations, not only in the military field will probably play a substantial role - whereby the armed forces could well play the role of a pioneer. Attention must be paid to the fact that the extended areas of interest can be agreed upon as a stable field of cooperation. In this respect neutrality is no longer a practicable instrument for achieving these goals, because:

Whoever is or wishes to remain neutral in the face of today's security policy challenges and global integration has already taken sides.

\section{Notes:}

1 <http://www.eda.admin.ch/sub_dipl/e/home/thema/intlaw/neutr.html> (22 June 2005).

2 <http://en.wikipedia.org/wiki/Hague_Conventions_(1899_and_1907)> (22 June 2005).

3 Jürg Martin Gabriel, "Die Gegenläufigkeit von Neutralität und Humanitären Interventionen" (Zürich: Center for Security Studies, Swiss Federal Institute of Technology, 1999) <http://ecollection.ethbib.ethz.ch/cgi-bin/show.pl?type=incoll\&nr=32> (22 June 2005). 
4 <http://www.vilp.de/Depdf/d198.pdf> (22 June 2005).

5 See Prof. Dr. Armin A. Steinkamm, "Der "Irak-Krieg:" Eine Herausforderung an das Völkerrecht," Wissenschaft \& Sicherheit 10 (December 2004), <www.sicherheitspolitik.de/ PDFs/WuS_10_2004_Steinkamm.pdf> (24 June 2005). From the military and political point of view, the pre-emptive strike has been considered not to be a fully-legitimised preventive attack. The legal dimensions of pre-emptive and preventive warfare will, however, not to be discussed here.

6 BBC News, 29 October 2004: Arabic TV station Al-Jazeera broadcasted excerpts of a videotape of Osama Bin Laden addressing the American people: (...) "Let him (President Bush) tell us why we did not strike Sweden, for example.” (...)

7 Gabriel, "Die Gegenläufigkeit von Neutralität und Humanitären Interventionen."

8 Dr. Thomas Hajnoczi, Europäische Sicherheits- und Verteidigungspolitik (ESVP), Österreichische Gesellschaft für Landesverteidigung und Sicherheitspolitik, Mitteilungsblatt 56 (Wien, 2004).

9 <http://europa.eu.int/pol/cfsp/overview_en.htm> (24 June 2005).

${ }^{10}$ Kurt R. Spillmann, Von der bewaffneten Neutralität zur kooperativen Sicherheit, Bulletin 1995 zur Schweizerischen Sicherheitspolitik (Zürich, 1995).

11 <http://europa.eu.int/constitution/en/ptoc2_en.htm\#a3> (24 June 2005).

${ }^{12}$ Gheorghe Fulga, "Rumänien und die regionale Sicherheit," Europäische Sicherheit 4 (April 2005).

${ }^{13}$ IHT, Terrorists and organized crime join forces, 25 May 2005.

${ }^{14}$ Reuters, 10 March 2005.

15 <http://de.wikipedia.org/wiki/Verkehrstote>: according to world-wide collections and estimations about one million (World Bank) up to 1.2 million (WHO 2003) humans die annually at the consequences of traffic accidents. The number of road casualty lies thereby far over victim numbers of war, genocide or terrorism.

${ }^{16}$ Heiko Borchert, "Vernetzte Sicherheitspolitik” (Büro für Sicherheitspolitik, Wien, 2004).

CHRISTIAN LANZ, LTC (GS), was born in July 1971. In 1998, he graduated the Military Academy at the Swiss Federal Institute of Technology Zurich (ETH Zurich) as a Swiss Federal Diploma Professional Officer VBS/ETH. From 1998 until 2001 he was Company Instructor at the Anti Tank Recruit School (Pzaw RS 16/216). Then he was appointed at the Intelligence Directorate, Military Analyst Strategic Intelligence Service, and since 2004 LTC Lanz has been Project Manager for Doctrine Research and Development. Address for correspondence: Armed Forces Planning Staff, Military Doctrine, Doctrine Research and Development, Swiss Department of Defence, Civil Protection and Sports, Papiermühlestrasse 20, CH-3003 Bern, Switzerland; Phone: ++41 (0) 3132419 05; Fax: ++41 (0)31 32254 45; E-mail: christian.lanz@vtg.admin.ch; Web: www.vbs-ddps.ch. 